\title{
STRATEGI PENGEMBANGAN NILAI-NILAI TOLERANSI DALAM RELASI SOSIAL SUNNI-SYI'AH DI PERKAMPUNGAN CANDI DESA BANJARAN-JEPARA
}

\author{
Fathimatuz Zahra \\ Dosen Sekolah Tinggi Agama Islam Pati \\ Email: ima59114@yahoo.com \\ Muhammad Ghufron \\ Email: muhammadghufron@gmail.com \\ Content Creator SMK CORDOVA Pati
}

\begin{abstract}
Differences are part of dynamic phenomenon of human communities that interact with each other. Because, religion as a source of inspiration for the creation of ethics, justice and sosial life as its main mission. Sunni and Syi'ah as historial facts for muslim in Indonesia. Both mazhab that have contributed in the process of indigenization of Islamic Nusantara. Now, these both mazhab are often bumped in difference. Escalation of conflict between the two increased until burning occurs and expulsion of Syi'ah groups at some places such as Sampang, Madura. This research is portraits occur in the Sunni-Syi'ah social space at Candi village Banjaran, Jepara. Researching dynamic of two communities Sunni-Syi'ab social relation at the Banjaran Village is established in a harmonious interaction, mutual respect in difference, upholding the values of peace and humanity. The result of this research showed the description of the development tolerance of both parties maintain brotherhood ukhuwah Islamiyah, through intercommunity of civic networks cultivation mutual trust in the pattern of negotiation and cooperation patern. As well as develop the power of social capital, cultural capital and symbolic capital in some activities that involve each other.
\end{abstract}

Keywords: Peace, Tolerance, Sunni, Syi'ah.

\begin{abstract}
Abstrak
Perbedaan merupakan bagian dari fenomena dinamika komunitas manusia yang saling berinteraksi, karena agama sebagai sumber inspirasi terciptanya etika, keadilan dan kehidupan sosial, sebagai misi profetiknya. Sunni dan Syi'ah sebagai kenyataan sejarah umat Islam di Indonesia, kedua maz̧bab yang telah berkontribusi dalam proses pribumisasi Islam Nusantara. Sekarang kedua mazhab ini kerap
\end{abstract}


berbenturan dengan perbedaan, eksalasi konflik antar keduanya meningkat hingga menjadi pembakaran dan pengusiran kelompok Syi'ah di beberapa tempat seperti Sampang, Sidoarjo dan Lombok Nusa Tenggara Barat. Penelitian yang mengambil potret ruang sosial Sunni-Syiah di Perkampungan Candi di desa Banjaran Jepara meneliti dinamika dua komunitas dengan relasi sosial yang terbangun dalam interaksi harmoni, keduanya saling menghormati dalam perbedaan, serta menjunjung tinggi nilai-nilai perdamaian dan kemanusiaan. Metode penelitian yang digunakan dengan field research, menggunakan pendekatan kualitatifyang humanistik tentang kehidupan masyarakat sosial dan fungsionalisasi jaringan kewargaan di dalamnya. Hasil penelitian ini menunjukkean gambaran tentang 'rekayasa' pengembangan nilai-nilai toleransi kedua belah pibak dalam menjaga ukhuwah insaniyah, melalui jariang kewargaan interkomunitas yang menumbubkan sikap saling mengenal dan saling percaya dalam pola negosiasi dan pola kerjasama serta mengembangkan kekuatan modal sosial, modal budaya dan modal simbolik dalam beberapa kegiatan yang saling melibatkan.

Kata kunci: Perdamaian, Toleransi, Sunni, Syi'ah.

\section{A. Pendahuluan}

Hadirnya sekte Islam Sunni dan Syi'ah adalah kenyataan sejarah umat Islam yang terus bergulir. Lebih dari 1000 tahun Syi' ah mengalami perjalanan sejarah, tidak serta merta hadir di panggung perdebatan dan konflik sosial seperti 10 tahun terakhir ini. Perbedaan yang berlangsung antara dua madzhab ini tidak memiliki sejarah konflik masa lampau, kecuali hanya berlangsung di level perdebatan argumentasi teologis atas klaim masingmasing pendapat yang otentik dan rasional, atau dalam kata lain mengaku 'benar'. Kelompok di luar Syi'ah memandang bahwa sebenarnya Syi' ah adalah kelompok sempalan Islam yang dibuat tokoh mualaf yahudi dari Yaman pada masa Khalifah Utsman (Akhir 30 H), Abdullah bin saba' untuk menghancurkan dan memecah belah umat Islam dari dalam. Berdasar pada pengertian Syi'ah menurut Quraish Shihab, yang pada intinya Syi'ah adalah kelompok yang mendasarkan paham keagamaan pada Ali bin Abi Thalib dan keturunannya 
(Ahlul Bait), maka benih kelompok Syi'ah sudah ada sejak awal kepemimpinan Islam pasca kerasulan Muhammad. ${ }^{1}$

Pandangan ini didukung oleh fakta adanya pertentangan di kalangan para Sahabat Nabi dengan Ahlul Bait (keluarga Nabi) setelah kematian Rasulullah Muhammad. Pada kenyataannya setelah Abu Bakar terpilih sebagai khalifah pertama, muncul pendapat bahwa sebenarnya Ali bin Abi Thalib lebih berhak memegang tapuk kepemimpinan Islam pada waktu itu. Pendapat yang mendukung Ali sebagai khalifah pertama beralasan bahwa Ali adalah orang terdekat Nabi, sebagai menantu dari anaknya, dan sebagai pintu dari keluasan ilmu Nabi. Selain itu, dalam perjuangan Islam, Ali juga tidak diragukan lagi pengorbanannya. Ketika peristiwa Ghodir Khumm, ${ }^{2}$ setelah Nabi menjalankan haji terakhir, Nabi memerintahkan pada Ali untuk memimpin rombongan umat Islam. Maka yang diyakini penganut Syi'ah, Khulafau Ar-rasyidin sebelum Ali adalah menyerobot hak Ali sebagai Amirul Mukminin setelah wafatnya Nabi.

Keputusan pengangkatan Abu Bakar As-Shiddiq sebagai khalifah pertama dalam perundingan antara kaum muhajirin dan Anshar di majlis Tasqifah Bani Sa'adah tanpa berunding dengan Ahlul Bait (keluarga Nabi) yang pada saat itu masih sibuk mempersiapkan acara pemakaman, mengecewakan pendukung Ali dan ahlu bait. Ali bin Abi Thalib pada waktu itu cukup bersabar dan menerima baiat atas Abu Bakar yang tidak dapat diubah lagi, hingga sampai pada kekhalifahan keempat Ali di bai'at sebagai Amirul Mukminin pasca wafatnya Khalifah Utsman bin Affan. ${ }^{3}$

\footnotetext{
${ }^{1}$ M. Quraish Shihab, Sunnab Syi'ah bergandeng tangan, Mungkinkah? Kajian Atas Konsep Ajaran dan Pemikiran (Tangerang: Lentera Hati, 2007) hlm. 65.

2 Peristiwa Ghadir Khumm adalah peristiwa sejarah Rasulullah pada perjalanan pulang setelah haji wada' bersama rombongan sahabat, berhenti pada suatu daerah bernama Khumm (antara makkah dan madinah). Nabi memerintahkan sahabat-sahabatnya untuk berhenti, kemudian menumpuk batu-batu untuk dijadikan sebagai mimbar. Kemudian nabi memberikan ceramahkepada 120.000 sahabat pada saat itu yang hadir dan ikut sebagai rombongan haji wada"e Nabi berkata "Man kuntu maula fa aliyyunmaula" Siapa yang menjadikan aku sebagai pemimpin maka Ali adalah pemimpin setelah aku. Lalu nabi memindahkan sorbannya kepada Ali sebagai simbol kepemimpinan dilanjutkan oleh Ali K.W.

3 M. Quraish Shihab, Sunnah Syi" ah bergandeng tangan, Mungkinkah? Kajian Atas Konsep Ajaran dan Pemikiran (Tangerang: Lentera Hati, 2007) hlm. 67.
} 


\section{B. Sunni - Syi'ah di Nusantara}

Sunni-Syi'ah yang menjadi dua aliran atau sekte besar Islam, dewasa kini menjadi sering menampakkan ketegangan dan konflik baik internasional (Irak, Syuriah, Lebanon, Arab Saudi dan Iran) hingga nasional (Jember, Sampang Madura, Bondowoso dan Lombok). Sejarah Sunni- Syi'ah di Indonesia yang telah lama bersama membawa misi perdamaian dalam penyebaran Islam di kepulauan Nusantara, demikian terpecah belah karena faktor klaim kebenaran dan kepentingan politik.

Sejarawan Slamet Muljana dalam bukunya Runtubnya Kerajaan Hindu Jawa dan Timbulnya Negara-Negara Islam, Teori Gujarat menyebutkan bahwa Islam yang sampai di Asia Tenggara tidak lepas dari jasa pengikut aliran Syi' ah yang dibawa oleh pedagang dari Gujarat, Persia, dan Arab ke Pantai Timur Sumatera, daerah Perlak dan Pasai Aceh, sehingga mendirikan sebuah kerajaan Samudra Pasai atau Kerajaan Perlak. Namun dalam proses perjalanannya terjadi persengketaan kekuasaan antar keluarga kerajaan berpaham Syi'ah dan paham Sunni, sehingga kerajaan ini terpecah menjadi dua bagian antara perlak pesisir yang menjadi bagian dari Syi' ah dan Perlak perdamaian untuk Sunni. ${ }^{4}$

Perlu digarisbawahi, kehadiran orang Syi'ah di Indonesia beserta kontribusinya terhadap perkembangan ajaran Islam kerap dinafikan. Martin Van Bruinessen mengatakan bahwa jejak-jejak representasi muslim Syi'ah itu dapat diamati dari peninggalan muslim suku Kurdi. Suku Kurdi merupakan penghuni wilayah Kurdistan yang berada di Pegunungan Utara dan Timur Laut Mesopotamia yang sekarang meliputi bagian utara Irak, bagian timur Turki dan bagian barat daya Iran.

Ulama Kurdi memiliki peran dan pengaruh yang signifikan dalam pola keberagaman umat Islam Indonesia. Salah satunya adalah kitab Barzanji yang dibaca setia kali ritus syukuran, perayaan atau maulidan. Barzanji sendiri adalah nama keluarga ulama dan syeikh tarekat Kurdi yang paling terkenal. Kebanyakan keluarga besar Barzanji menganut

\footnotetext{
4 Media Tempo Kisah Kang Jalal Soal Syi’ah Bagian 1-5 diakses 
dan mengembangkan tarekat Qadiriyah. Syeikh Abdul Qadir Jaelani, yang dianggap sebagai pendiri tarekat ini sangat populer di Kurdistan.

Atas dasar inilah maka sesungguhnya Syi'ah telah menjadi bagian integral dari proses Islamisasi di Indonesia. Meski belum ada bukti otentik yang menunjukkan bahwa mereka yang kali pertama melakukan dakwah di Nusantara, tetapi ulama Kurdi yang Syi'ah itu telah menghadirkan sesuatu yang tidak pernah dihadirkan oleh yang lain. Agama adalah sumbu inspirasi terciptanya etika, keadilan dan kehidupan sosial, sebagai misi profetiknya, seharusnya agama mengakomodasi serta menjunjung nilai-nilai perbedaan sebagai bagian dari keragaman. Akan tetapi kontra visioner apabila agama dipahami dan dipraksiskan sebagai entitas yang mengekang dan eksklusif, serta mendidik umatnya untuk saling membenci dan menjaga jarak dengan gologan yang berseberangan pemahaman. ${ }^{5}$

Komaruddin Hidayat, menganalogikan keragaman ini dalam bukunya "Agama Punya Seribu Nyawa" seperti sungai-sungai yang mengalir dari berbagai penjuru arah melintasi daratan, lembah, gunug, dan pada akhirnya bermuara pada satu samudera. Tentu maksud dari semua ini bukan menyamakan semua agama, tetapi pada esensi maknanya semua makhluk memiliki fitrah sebagai penyembah yang secara otopraksis menjunjung tinggi asma Tuhan yang masing-masing imani.

\section{Sunni-Syi'ah dalam pusaran konflik}

Di Indonesia eskalasi peningkatan konflik antara Sunni-Syi'ah kian meningkat, misalnya berita perlakuan kekerasan dan vandalisme yang kerap terjadi di Jawa Timur bagai karnaval berdarah. Menurut catatan kejadian MUI rentetan konflik Sunni-Syi'ah dari tahun 2000 hingga 2012 tercatat kasus konflik. ${ }^{6}$ Pertama, Penghancuran dan pembakaran pondok pesantren Al-Hadi di desa Brokoh kec. Wono Tunggal, kab. Batang Jawa Tengah pada 14 April 2000. Peristiwa ini mengakibatkan hancurnya rumah warga Syi'ah dan satu mobil dirusak, dan gudang material bangunan dibakar. Kedua, demo anti Syi'ah di Bondowoso Jawa Timur pada tanggal 24 Desember 2006, yang berujung konflik, sehingga mengakibatkan hancurnya 3 rumah dan 2 musala. Ketiga, penyerangan masa oleh kelompok

\footnotetext{
${ }^{5}$ Hendrianto Attan, Islam Universal, (Yogyakarta: Pustaka Pelajar, 2007) hlm. 57

6 Mohamad Baharun (Ed), Mengenal dan Mewaspadai Penyimpangan Syi" ab di Indonesia (Jakarta: Al-
} Qalam, 2013) hlm. 62. 
Aswaja di Karang Gayam Sampang Madura, yang terjadi pada tanggal 9 April 2007. Pada perayaan maulid Nabi di komunitas Syi'ah.

Keempat, pada 20 April 2007 organisasi masa Islam (Muhammadiyah, PERSIS, Nahdlatul Ulama) yang menamakan diri sebagai kelompok HAMAS di bawah pimpinan Habib Umar Assegaf melakukan penekanan pada pesantren Syi'ah di Bangil, Jawa Timur. Kelima, pembubaran kegiatan kelompok Syi'ah yayasan Al-Qurba di Lombok Nusa Tenggara Barat, pada tanggal 13 januari 2008. Keenam, pembakaran rumah dan tempat ibadah komunitas Syi'ah di desa Karang Gayam Sampang untuk kesekian kali terjadi. Hingga masyarakat diungsikan di gedung olahraga Sampang. Pada tanggal 29 Desember 2011.

Ketujuh, Konflik Sunni-Syi'ah di Sampang kembali memuncak pada tanggal 26 agustus 2012. Kekerasan mengemuka saat perayaan maulid di Pesantren Syi'ah Hingga menyebabkan seorang warga Syi'ah meninggal dunia dan masyarakat Syi'ah kini direlokasi di Rusun Puspa Agro Sidoarjo. Rangkaian aksi anarkis warga yang melakukan penyerangan pada kelompok minoritas Syi'ah tercatat telah megakibatkan 2 orang tewas, 13 orang terluka, 37 bangunan (rumah dan musala) hangus terbakar.

\section{Sunni-Syi'ah dalam Ukhuwah}

Namun, hal ini tidak berlaku di Banjaran Bangsri Jepara, Jawa Tengah. Di kota ini muslim Sunni dan Syi'ah menjalin hubungan interaksi secara baik di berbagai bidang khususnya sosial-keagamaan. Hal ini dibuktikan dengan kesepakatan perdamaian antar warga dan lintas ormas agama yang dideklarasikan di Jepara. Difasilitasi oleh pemerintah dan Polres Jepara bersama tokoh agama dan pimpinan ormas PCNU Jepara, PD Muhammadiyah, MUI, KNPI, ABI Jepara (Ahlu Bait Indonesia-Ormas Syi'ah), Banser Nahdlatul Ulama, Kokam Muhammadiyah, Fatayat Nahdlatul Ulama, UNISNU, PMII Jepara dan tokoh Agama Hindu-Buddha, menyepakati "Jepara berbhinneka, NKRI Harga Mati”.

Potret muslim Syi'ah di Kecamatan Bangsri Jepara bukanlah cerita tentang sebuah komunitas yang besar. Sebagaimana komunitas Syi'ah di daerah lainnya, Syi'ah di Banjaran adalah minoritas dari mayoritas kelompok Sunni di daerah Bangsri, dengan prosentase 
sekitar 6\% (sekitar 800 warga) dari mayoritas muslim di Bangsri. Tersebar diberbagai desa di kecamatan Bangsri, yakni; Desa Banjaran, Desa Kauman, Desa Guyangan, Desa Pakis Aji, Desa Krasak-Mlonggo, dan Desa Krapyak-Tahunan. ${ }^{7}$ Syi'ah di Bangsri pada awal perkembangan syiarnya tidak menyematkan nama ataupun istilah Syi'ah dalam gerakannya. Peran Abdul Qadir Bafaqih ${ }^{8}$ dari Tuban yang sejak tahun 1979 pertama mensyiarkan nilainilai ajaran ahl al-bait secara taqiyyah dengan damai di Bangsri.

Abdul Qadir Bafaqih yang dikenal sebagai guru Bahasa Arab mengajar beberapa santri yang tidak membedakan siapa yang diajarinya dari Sunni (Nahdlatul Ulama atau Muhammadiyah) atau syi'i, di pondok pesantren yang didirikannya “Al-Khairat” Kauman. Metodologi pengajarannya yang adaptif dan akomodatif terhadap sistem pengajaran tradisional pesantren NU seperti sorogan dan bandongan, tidak menjadikan muridmuridnya yang Sunni merasa asing terhadap gurunya, meskipun berseberangan pandangan. Model ini terus dipakai dalam pesantren Al-Khairat sebagai proses mengajar hingga Abdul Qadir Bafaqih wafat pada tahun 1993.

Embrio entitas Syi'ah berpaham toleran di Bangsri yang telah dirintis oleh Abdul Qadir Bafaqih dan membawa dinamika positif pada konteks interaksi sosial masyarakat Desa Banjaran. Beberapa organisasi Syi'ah terus muncul dibawah naungan ABI Jepara (Ahlu Bait Indonesia). Ormas Islam Syi'ah ini sebagaimana organisasi masa Islam pada umumnya seperti Nahdlatu Ulama dan Muhammadiyah. ABI Jepara juga memiliki organisasi Fathimiyah (wadah organisasi ibu-ibu warga Syi'ah seperti halnya muslimat NU, dan Aisyah milik Muhammadiyah), organisasi Zainabiyah (sebagai organisasi Syi'ah yang melaksanakan kegiatan-kegiatan pengajian remaja putri seperti organisasi fatayat NU), HIKMAT (Organisasi sosial) dan Yayasan Darut Taqrib (bidang pendidikan).

Lahirnya organisasi-organisasi Syi'ah di bawah naungan ABI Jepara bukan bertujuan sebagai bentuk perlawanan pemikiran terhadap kelompok mayoritas Sunni atau bentuk penyeimbangan kelompok kegiatan, melainkan bentuk partisipasi memperkuat

7 Wawancara dengan Ustadz Ali - Tokoh Syi'ah di desa Krapyak - Tahunan, 7 Juni 2017.
${ }^{8}$ Nama lengkapnya adalah Al-Ustadz Abdul Qadir bin Abu Bakar Bafaqih (meninggal 17 Agustus 1993). Pernah menempuh studi di Hadramaut Yaman, dan menikah dengan Nur Imanah binti Umar bin Muhsin Al-Athas (meninggal 4 April 1994). 
posisi umat Islam, dengan dilatari oleh pembangunan sumber daya insaniyah yang Islami. Terciptanya persatuan antar umat Islam dan upaya pembentukan kepribadian dan sikap saling menghormati dan menghargai perbedaan pendapat dan paham, adalah nilai-nilai yang dijunjung Ormas Nahdlatul Ulama-Muhammadiyah dan ABI Jepara.

\section{E. Relasi Sosial Sunni- Syi'ah Desa Banjaran}

Desa Banjaran merupakan satu dari 12 desa di kecamatan Bangsri yang memiliki luas wilayah 510,072 $\mathrm{Ha}$ atau 5,10 KM2, dengan jumlah penduduk pada tahun 2015 sebanyak 8.508 jiwa, geografis yang strategis karena terletak persis di timur pusat pemerintahan kecamatan $3 \mathrm{KM}$ Bangsri atau $17 \mathrm{KM}$ dari pusat Kabupaten Jepara. Desa dengan sejarah penamaannya diambil dari tokoh spiritual bernama Ki Banjar ini, seluruh masyarakatnya adalah pemeluk agama Islam, namun memiliki keunikan yang tidak dimiliki beberapa desa lain di kabupaten Jepara. Salah satunya ialah berkembangnya madzhab pemikiran Islam Syi'ah terbesar di Jawa Tengah dengan jumlah 206 KK dari 2.343 KK, atau sekitar 8,79\% dari populasi masyarakat desa Banjaran secara umum, sebagian besar bermukim di wilayah RW 1 Banjaran bagian Utara. ${ }^{10}$ Meski hitungan rasio perbandingan menggolongkan komunitas ablu bait Syi'ah sebagai golongan minoritas dari komunitas Sunni (Nahdlatul Ulama), orang-orang Syi'ah di Banjaran tidak tertutup dalam berkomunikasi dan membangun relasi sosial dengan masyarakat Sunni.

\section{F. Relasi Sosial Sunni - Syi'ah Banjaran}

Keberadaan Sunni dan Syi'ah di desa Banjaran tidak terjebak dalam pola identitas madzhab yang menampilkan perbedaan, sebaliknya, orang Sunni dan ablu bait Syi'ah saling menjalin hubungan erat dalam berinteraksi baik dalam bidang sosial, ekonomi dan keagamaan, tanpa membedakan dari kalangan Sunni atau Syi'ah. Oleh sebab itu, dalam mencari data antar komunitas Sunni-Syi'ah secara akurat, sedikit mengalami kekaburan data, karena Sunni-Syi'ah di desa Banjaran telah membaur dan melebur menjadi satu identitas sebagai Orang Jepara. Penyebutan Sunni- Syi’ah merunut pada ketika melakukan

\footnotetext{
9 "Profil Yayasan Darut Taqrib", http://daruttaqrib. org/ diakses pada 2 Januari 2016 pukul 21.00.

10 Kecamatan Bangsri dalam angka 2016 -diterbitkan oleh BPS Jepara.
} 
peribadatan jama'ah, di mana jama'ah ablu bait Syi'ah di RW 1 aktivitas keagamaannya terpusat di Mushalla Al-Husaini.

Syi'ah yang berkembang di Banjaran- Jepara dan mayoritas di Indonesia adalah penganut Syi'ah Ja'fariyah - Imam Ja'far Shodiq, atau juga dikenal sebagai Itsna Asyariyah yakni kelompok Syi'ah yang mempercayai ada 12 imamah yang kesemuanya adalah keturunan dari Ali bin Abi Thalib dan Fatimah Az Zahra, Putri Rasulullah SAW. Dalam struktur sosial masyarakat desa Banjaran, tipologi masyarakat Sunni-Syi'ah tidak terlihat banyak perbedaan. Meskipun sebagian kecil masyarakat Syi'ah adalah pendatang baru di desa Banjaran hasil dari pernikahan dengan warga Syi'ah Banjaran, namun tidak tampak perbedaan kecuali dalam dialek logat bahasa.

Setiap warga desa Banjaran sudah memahami kondisi perbedaan madzhab Islam yang terjadi di desanya telah ada berpuluh-puluh tahun, dari awal perkembangannya berlangsung damai, sehingga tidak sulit bagi masyarakat untuk saling menghormati dan menghargai perbedaan yang ada. Komunitas Syi'ah desa Banjaran sebagian besar bermukim di wilayah RW 1 dengan sebaran di RT 2, RT 3 dan RT 4, serta beberapa orang-orang Syi'ah juga tersebar di desa-desa sekitar Bangsri, seperti daerah Kauman desa Bangsri, desa Guyangan dan desa Krasak.

Ruang lingkup keorganisasian Syi'ah seperti Ahlu Bait Indonesia, Fatimiyah, dan Zainabiyah memang tidak seperti lembaga Nahdlatul Ulama yang ada pengurusnya disetiap ranting desa. Lembaga keagamaan Syi'ah hanya ada di level kecamatan dan kabupaten, sehingga setiap perayaan kegiatan keagamaan Syi'ah berpindah-pindah pusat aktifitasnya sesuai kesepakatan. Pasca revolusi Iran tahun 1979, arus kedua perkembangan Syi'ah di Indonesia, nilai-nilai ajaran ablu bait Syi'ah mulai di syiarkan di daerah Bangsri oleh tokoh agama bernama Habib Abdul Qodir Bafaqih dari Tuban.

Penyampaian ajaran Syiah dilakukan beliau di madrasah-madrasah sebagai ustadz atau pengajar bahasa Arab, pengajiannya tidak hanya diikuti oleh kalangan Sunni-Syi'ah di Jepara, namun ada juga santri dari Kudus dan Demak dan sekitarnya. Pondok Pesantren Al- Khairat yang didirikannya tahun 1980-an di daerah Kauman Bangsri 3 KM dari desa 
Banjaran, hingga tahun 1993 masih ramai diisi santri-santri Syi'ah dari berbagai daerah di Indonesia.

Kharisma Habib Abdul Qadir Bafaqih yang santun dalam berdakwah, membawa pengaruh besar dalam pesatnya penyebaran ajaran abl bait Syi'ah hingga desa Banjaran dan sekitarnya. Pesantren Al-Khairat sebagai embrio hadirnya Syi'ah di desa Banjaran Bangsri kini tidak lagi eksis, karena penerus dari keluarga Habib Qadir Bafaqih tidak ada yang melanjutkan, maka lembaga pendidikan keagamaan Syi'ah Jepara sekarang terpusat di Pesantren Darut Taqrib, desa Krapyak kecamatan Tahunan, 21 KM dari Banjaran Bangsri. ${ }^{11}$

\section{G. Jaringan Kewargaan Interkomunitas; Pola Negosiasi dan Kerjasama}

Toleransi bermakna memberi kebebasan (membiarkan) pendapat orang lain, dan memberikan tempat kepada pendapat yang berbeda. Masing-masing pendapat memperoleh hak untuk mengembangkan pendapatnya dan tidak saling menjegal satu sama lain. Hubungan toleransi Sunni-Syi'ah di desa Banjaran terjadi dalam beberapa bentuk; pola negosiasi dan pola kerjasama antar komunitas. Konsepsi ini diperhatikan dari apa yang terjadi di ruang sosial dan ruang akademik masyarakat desa Banjaran. Apa yang dikembangkan oleh kedua organisasi Islam dalam meningkatkan toleransi antar keduanya.

\section{H. Terbukanya Ruang Sosial-Agama}

Pada pola negosiasi terlihat keterbukaan antar dua komunitas, terutama pada hubungan kesepakatan damai masyarakat Sunni-Syi'ah dalam wadah jamiyyah Muawanah dan organisasi sosial HIKMAT, wadah yang menjadi ruang besama dalam membahas hubungan kemasyarakatan dan kegiatan-kegiatan sosial yang melibatkan dua komunitas Sunni dan Syi'ah. Kepemimpinan dalam organisasi Jamiyah Muawanah juga dilakukan secara bergilir, di mana setiap periode berganti tokoh Sunni dan Syi'ah secara bergantian. Pertemuan besar antar tokoh dilaksanakan setahun sekali ketika menjelang perayaan hari idul fitri, dan pertemuan rutinan dilaksanakan setiap satu bulan sekali.

Kegiatan pemberdayaan yang dilakukan oleh HIKMAT juga dilaksanakan secara bersama lintas madzhab, dengan sasaran kegiatan keluarga kurang beruntung (unfortunate) di

11 Wawancara dengan Ustadz Ali, Kepala Asrama PP Darut Taqrib, 7 Juni 2017. 
daerah Bangsri dan sekitarnya tanpa melihat aliran madzhab. Pola negosiasi dan kerjasama antar komunitas Sunni dan Syi'ah di desa Banjaran Jepara adalah bentuk preventif membangun jaringan kewargaan (civic networking) sebagai upaya menumbuhkan sikap saling mengenal, saling percaya antar komunitas masyarakat (Interpersonal Trust). Sebagaimana dalam kajian Ashutosh Varshney dalam artikelnya Ethnic Conflict and Civil Society; India and Beyond.

Artikel ini berpendapat bahwa ada kaitan integral antara struktur kehidupan sipil di masyarakat multietnis, ada dan tidak adanya kekerasan dapat dilihat dalam hubungan: pertama keterlibatan masyarakat dalam pola relasi intra-komunitas (intra-community engagement) dan inter-komunitas (intercommunity engagement). Kedua, jaringan kewargaan (civic engagement) yang terorganisir formal dan kultural. Pembedaan ini didasarkan pada apakah interaksi masyarakat bersifat formal atau bersifat kultural sehari-hari.

Pada konteks Banjaran, jaringan kewargaan inter-komunitas dalam bentuk asosiasi masyarakat formal (civic association) bisa dilihat dalam asosiasi Jamiyyah Muawanah dan HIKMAT, dan dalam bentuk informal atau bisa disebut jaringan kultural seperti ziarah bersama, tahlil, perayaan maulid Nabi, barzanji dan istighosah serta peringatan haul mbah Muhammad Arif yang selalu terselenggara setiap tahun. Namun argumentasi Varshney dalam melihat urgensi relasi antar komunitas (inter-community engagement) belum cukup untuk menjawab strategi toleransi preventif di Indonesia.

Kemajemukan dan kultur relijiusitas masyarakat Indonesia yang cenderung menempatkan strata pemuka agama sangat tinggi dan menjadi tokoh sentral dalam berbagai persoalan, berpotensi menjadi pemicu pertikaian antar komunitas. Seperti yang terjadi pada konflik Sunni-Syi'ah di Sampang Madura tahun 2006 dan 2011, upaya rekonsiliasi tidak menemukan titik penyelesaian karena tradisi Bheppa", Bheppu, Gurub Ratoh atau keputusan tertinggi masyarakat ada ditangan pemimpin agamanya (ulama) justru menjadi kendala rekonsiliasi. $^{12}$

Tentu tidak semua tokoh-tokoh agama memiliki kesadaran sikap toleransi dan prokoeksistensi. Ketika segregasi elit terjadi, atau bahkan elit cenderung membangun wacana

12 Mundiroh Lailatul Munawaroh, Tesis; Penyelesaian Konflik Sunni - Syi'ah di Sampang Madura, UIN Sunan Kalijaga. Yogyakarta: 2014. 
intoleran, persekusi yang mengancam integrasi, maka relasi ditingkat massa dalam jaringan kewargaan (civil engagement) tidak cukup kuat membendung konflik perpecahan. Pada konteks Sunni-Syiee ah di Jepara, Integrasi elite dan penambahan kebijakan internal (self policing) terselenggara dengan adanya deklarasi 'Jepara Damai' antara tokoh lintas iman dan Forum Koordinasi Pimpinan Daerah Jepara (Forkopimda). Anjuran damai yang dikampanyekan dan disepakati tokoh lintas iman dan ormas seperti; Nahdlatul Ulama, Muhammadiyah, Ahlu Bait Indonesia (Syi'ah), Kristen, Katholik, Hindu dan Buddha menjadi suatu mekanisme kebijakan internal yang menyempurnakan strategi pengembangan nilai-nilai toleransi di Jepara.

Pada kehidupan masyarakat Banjaran, hubungan harmonis yang terbangun ditingkat elite antar madzhab berjalan dalam kehidupan sehari-hari. Pola hubungan komunikasi dalam lingkaran elite agama yang saling membutuhkan dan bekerjasama dalam kegiatan internal, eksternal maupun komunal antar komunitas, semuanya berlangsung baik. Setiap kegiatan yang bersifat sosial pemberdayaan, semuanya melepas baju kepentingan, madzhab ataupun golongan dan mengutamakan hak-hak komunal (communal rights) lebih dominan. Dua komunitas menjadi satu masyarakat yang utuh dengan sikap kemanusiaannya.

Terselenggaranya program-program sosial yang melibatkan tokoh Sunni-Syi'ah menjadi keteladanan sikap, dengan penanaman nilai-nilai baik yang menguatkan persaudaraan di masyarakat, atau dalam istilah Menchik bentuk toleransi komunal (communal tolerance). Jeremy Menchik (2016) dalam kajiannya Islam and Democracy in Indonesia: Tolerance Without Liberalism, mengapresiasi bagaimana masyarakat Indonesia menciptakan nilainilai demokrasi yang berbasis agama, atau dalam bahasa dia, toleransi tanpa liberalisme (tolerance without liberalism). ${ }^{13}$

Di level warga, kerukunan dan toleransi terjaga karena beberapa faktor; pernikahan silang, titik temu ritual amaliyah, perasaan ikatan persaudaraan keluarga, hingga ruang sosial-agama bersama. Pernikahan silang terjadi sejak periode awal perkembangan Syi ${ }^{\text {ee }}$ ah tahun 1980-an hingga kini semakin banyak keluarga yang berbeda-beda dalam satu atap

13 Jeremy Menchik. Islam and Democracy in Indonesia: Tolerance Without Liberalism. (Cambridge University Press, 2016), hlm 9. 
rumah tangga. Sejak saat itu, varian pernikahan silang atau keluarga lintas madzhab sudah lazim di desa Banjaran Bangsri.

Hubungan pernikahan silang dan keluarga lintas madzhab menjadi bagian penting, relasi utama warga desa Banjaran membangun hubungan harmoni karena terikat pertalian kekeluargaan, sebagai sistem yang menjembatani (bridging) dan menghubungkan (linking) kesenjangan sosial (social gap) serta melunturkan krisis kepercayaan yang selama ini terlihat pada dua kelompok Sunni-Syi'ah di beberapa daerah.

\section{Modal Sosial, Modal Budaya \& Modal Simbolik}

Ada banyak definisi yang dikemukakan oleh para ahli tentang modal sosial (Social Capital). Beragamnya definisi dari pada ahli biasanya tergantung pada objek riset mereka. Perbedaan objek riset itulah yang menyebabkan perbedaan harfiyah definisi modal sosial. Robert D. Putnam (1993) seorang pakar Ilmu Politik Amerika, mendefinisikan modal sosial secara berbeda antara ketika melakukan riset pada tradisi politik di Italia dan riset di masyarakat Amerika.

Piere Bourdieu (1972), seorang Sosiolog asal Perancis yang meneliti masyarakat Eropa dan berfokus pada kelas sosial dan ketidakadilan sosial, juga memaknakan modal sosial dengan warna yang berbeda pula. Demikian juga pakar-pakar lainnya. Salah satu definisi modal sosial yang cukup populer untuk difahami dalam teori Robert Putnam, modal sosial adalah fitur dari kepercayaan sosial, norma-norma, dan jaringan yang dapat meningkatkan efisiensi masyarakat terhadap suatu tindakan.

Kepercayaan sosial (Interpersonal Trust), dan norma-norma yang berlaku terkait resiprositas ditaati bersama dengan jaringan kewargaan kuat, yang kesemuanya bisa digunakan bersama untuk berbuat lebih efektif untuk mencapai tujuan bersama. Pada konteks melihat bentuk potensi modal (Forms of Capital) dalam nilai-nilai toleransi SunniSyi ${ }^{i e}$ ah di desa Banjaran yang berkembang dengan adanya hubungan modal sosial (social capital), modal budaya (culture capital), dan modal simbolik (simbolyc capital). Jejaring sosial yang telah terbangun, terbukanya ruang sosial-agama, pernikahan silang dan persaudaraan lintas madzhab dalam satu keluarga menjadi fondasi modal sosial Sunni-Syi'ah di Banjaran, sehingga dipertemukan dalam relasi hubungan kultural (cultural capital) ritual-ritual amaliyah secara bersama. Persaudaraan yang diwujudkan dengan kebersamaan menjalani amaliyah 
seperti: Tahlilan kematian, Ziarah Kubur, Istighosah, Pembacaan Maulid Nabi Diba"i dan Barzanji secara berjamaah Sunni-Syi'ah, melunturkan sekat-sekat perbedaan di antara penduduk Banjaran.

"Social capital refers to features of social organization, such as trust, norms, and networks, that can improve the efficiency of society by facilitating coordinated actions ${ }^{\text {"14 }}$

Dengan demikian, modal sosial (social capital) yang dimiliki masyarakat desa Banjaran dari jaringan kewargaan, pernikahan silang, serta perasaan persaudaraan, menumbuhkan sikap saling percaya dan norma-norma yang menguatkan kedua kelompok Sunni-Syi'ah, selanjutnya berkembang pada modal budaya (cultural capital) dalam pertemuan ritual amaliyah bersama, mewujudkan toleransi positif dalam keserasian budaya yang kemudian dilanjutkan dalam distribusi modal budaya di ruang akademik (role model education), sebagai titik awal pembentukan habitus yang baik.

\section{J. Kesimpulan:}

Dinamika sosial yang terjadi di desa Banjaran antara komunitas Sunni-Syi'ah, memberikan gambaran tentang rekayasa pengembangan nilai-nilai toleransi yang diinisiasi oleh kedua belah pihak dalam menjaga ukhuwah insaniyah, ukhuwah islamiyah, sekaligus bentuk preventif terhadap kekerasan atas nama agama. Jaringan kewargaan (civic networks) yang menumbuhkan sikap saling mengenal, dan saling percaya (interpersonal trust) dalam pola negosiasi dan pola kerjasama ditingkat elit hingga massa. Jaringan kewargaan yang dibentuk secara formal di desa Banjaran dalam wadah; (1) Jam'iyah Muawwanah, (2) Perkumpulan HIKMAT, (3) Deklarasi Jepara Damai, menjadi media yang menjembatani perdamaian lintas kelompok di Jepara dan khususnya desa Banjaran. Jaringan kewargaan juga diperkuat dengan proses yang membentuk kohesivitas perdamaian Sunni-Syi'ah di desa Banjaran seperti; (1) Keluarga lintas madzhab, (2) Pernikahan silang, dan (3) Perasaan persaudaraan. Sedangkan pada proses mengeratkan suasana harmonis di desa Banjaran, tergambar pada pola kerjasama dalam terbukanya ruang sosial-agama; (1) Peringatan Haul Mbah Muhammad Arief, (2) Perayaan Maulid Nabi Muhammad dengan pembacaan Barzanji dan

14 Robert. D. Putnam, Making Democracy work; civic tradition in Modern Italy, (Pricceton University 1993), hlm 167. 
Addiba"i, (3) Empati dalam tahlil kematian. Kemudian pada proses menjaga nilai-nilai perdamaian secara berkelanjutan, kekuatan simbolik antara komunitas Sunni-Syi'ah di desa Banjaran melakukan kegiatan yang bersifat sosial dan akademik, di antaranya; (1) Bantuan sosial, pemberdayaan masyarakat bedah rumah tidak layak huni (RTLH), (2) kegiatan lingkungan, fogging pencegahan demam berdarah dan penanaman mangrove, dan (3) Dialogdialog perdamaian yang diikuti pelajar dan santri dari Sunni - Syi’ah dan lintas iman. 


\section{Daftar Pustaka}

Shihab, M. Quraish, 2007, Sunnah Syi'ah bergandeng tangan, Mungkinkah ? Kajian Atas Konsep Ajaran dan Pemikiran, Tangerang: Lentera Hati.

Attan, Hendrianto, 2007, Islam Universal, Yogyakarta: Pustaka Pelajar.

Baharun, Mohamad (Ed), 2013, Mengenal dan Mewaspadai Penyimpangan Syi" ab di Indonesia, Jakarta: Al-Qalam.

Wawancara dengan Ustadz Ali - Tokoh Syi'ah di desa Krapyak - Tahunan, 7 Juni 2017.

"Profil Yayasan Darut Taqrib", http://daruttaqrib. org/ diakses pada 2 Januari 2016 pukul 21.00.

Kecamatan Bangsri dalam angka 2016 -diterbitkan oleh BPS Jepara.

Mundiroh Lailatul Munawaroh, Tesis; Penyelesaian Konflik Sunni-Syi'ab di Sampang Madura, UIN Sunan Kalijaga. Yogyakarta: 2014.

Menchik, Jeremy, 2016, Islam and Democracy in Indonesia: Tolerance Without Liberalism, Cambridge University Press.

Putnam, Robert. D., 1993, Making Democracy work; civic tradition in Modern Italy, Pricceton University.

Media Tempo Kisah Kang Jalal Soal Syi'ah Bagian 1-5 (https://m.tempo.co/read/news/2012/09/03/173427062/kisah-kang-jalal-soalSyi ah-indonesia) diakses pada tanggal 02 januari 2016 pukul 21.14 WIB

Wawancara dengan Ustadz Ali, Kepala Asrama PP Darut Taqrib, 7 Juni 2017. 